\title{
The Bull's-eye Tongue: A Case of Extensive Physiological Pigmentation of the Tongue
}

\author{
Geon Pauly*, Roopashri Rajesh Kashyap, Gowri P Bhandarkar, Raghavendra Kini, Prasanna Kumar Rao and \\ Ashwini Baliga
}

Department of Oral Medicine and Radiology, AJ Institute of Dental Sciences, India

Submission: November 06, 2017; Published: January 19, 2018

*Corresponding author: Geon Pauly N, Department of Oral Medicine and Radiology, AJ Institute of Dental Sciences, India, Tel: +918905102696; Email: geonpauly@gmail.com

\section{Abstract}

Pigmented lesions are commonly found in the oral cavity. Pigmentation has a multi factorial aetiology. Most of the oral pigmentations are physiologic but sometimes it can be a precursor of severe diseases. Evaluation of a patient presented with a pigmented lesion should include a full medical and dental history, extra-oral and intraoral examinations and even in some cases biopsy and laboratory investigations are required. In this article, we report a case of extensive physiologic pigmentation on the tongue in a 35-year-old female patient.

\section{Case Report}

A 35-year-old medically fit female patient presented with a chief complaint of pigmentation on the tongue. She gave a history of its presence since well over 10 years, with no change in colour and size, and was totally asymptomatic. There was no history of trauma to the area. The patient was in good health and was not taking any medications. Her past dental, medical, and personal history was non-contributory. Extra-oral examination revealed no significant findings. Lymph nodes were not palpable. Intraoral examination showed a well-demarcated, smooth, dark brownishblack pigmented lesion, present on the anterior tip, the posterior third and the right, left dorsolateral borders of the tongue with only the middle portion of the anterior one-third remaining unaffected giving it a symbolic 'bull's-eye' appearance (Figure 1).

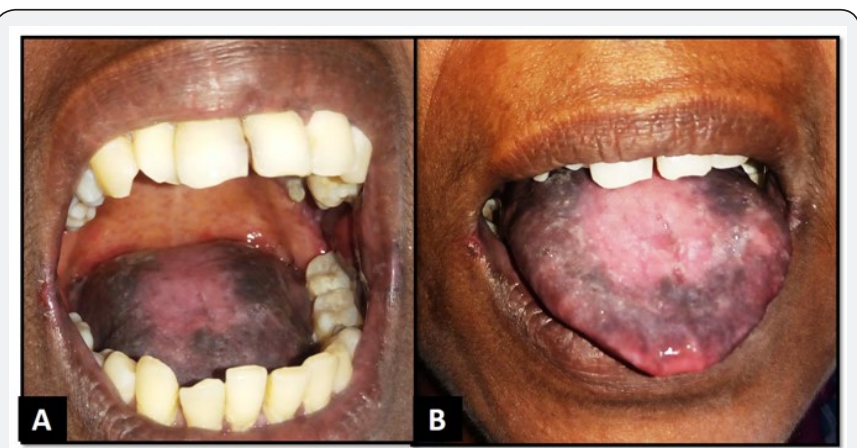

Figure 1: Physiological Pigmentation of Tongue in Dormant (A) and Protruded (B) Positions.

There were similar pigmentations seen on the right and left buccal mucosa, which were discrete and less extensive compared to the tongue. No other marked deformity or pigmented lesion was noted extra-orally or intra-orally. A thorough systemic examination of the patient was performed and hailed non-contributory. The patient was educated and assured that it was just a physiological variation and there was nothing to be concerned with.

\section{Discussion}

Human oral mucosal epithelium is not uniformly coloured and several degrees of chromatic variegation may be observed in physiologic and pathologic conditions. The term 'pigmentations of the oral mucosa' may be applied to a wide range of entities caused by the accumulation of one or more pigments and featuring a change in colour of the tissues [1]. Various stimuli, such as trauma, hormonal changes, medication, and radiation may result in an increased production of melanin. An age-related increase of oral melanocytes has also been observed [2,3].

Physiologic pigmentation, which is common in African, Asian, and Mediterranean populations, is due to greater melanocyte activity rather than a greater number of melanocytes. Physiologic pigmentation develops during the first decades of life but may not come to the patient's attention until later. The colour ranges from light to dark brown. The attached gingiva is the most common intraoral site of such pigmentation, where it appears as a bilateral, well-demarcated, ribbon-like, dark brown band that usually spares the marginal gingiva. Pigmentation of the buccal mucosa, hard palate, lips, and tongue may also be seen as brown patches with less well-defined borders. The physiologic pigmentations are predominately asymptomatic, and no treatment is required [4]. 
Hence to conclude, pigmentation is the process of deposition of pigments in tissues. Various diseases can lead to varied colourations in the mucosa. It can arise from intrinsic and extrinsic factors and can be physiological or pathological. The dentist should thus be aware of the various lesions, so as to aid in the timely and appropriate treatment plan.

\section{References}

1. Kauzman A, Pavone M, Blanas N, Bradley G (2004) Pigmented Lesions of the Oral Cavity: Review, Differential Diagnosis, and Case Presentation. J Can Dent Assoc 70(10): 682-683.

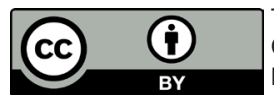

This work is licensed under Creative Commons Attribution 4.0 Licens

DOI: 10.19080/ADOH.2018.07.555712
2. Ciçek Y, Ertas Ü (2003) The Normal and Pathological Pigmentation of Oral Mucous Membrane: A Review. J Contemp Dent Pract 4(3): 76-86.

3. Amir E, Gorsky M, Buchner A, Sarnat H, Gat H (1991) Physiologic Pigmentation of the Oral Mucosa in Israeli Children. Oral Surg Oral Med Oral Pathol 71(3): 396-398.

4. Chandra S, Keluskar V, Bagewadi A, Sah K (2010) Extensive Physiologic Melanin Pigmentation on the Tongue: An Unusual Clinical Presentation. Contemp Clin Dent 1(3): 204-206.

\section{Your next submission with Juniper Publishers will reach you the below assets}

- Quality Editorial service

- Swift Peer Review

- Reprints availability

- E-prints Service

- Manuscript Podcast for convenient understanding

- Global attainment for your research

- Manuscript accessibility in different formats

( Pdf, E-pub, Full Text, Audio)

- Unceasing customer service

Track the below URL for one-step submission https://juniperpublishers.com/online-submission.php 